\title{
HUBUNGAN ANTARA TINGKAT PENGETAHUAN TENAGA KESEHATAN TENTANG PENYEBARAN INFEKSI DENGAN KEPATUHAN MENCUCI TANGAN (FIVE MOMENT) DI RSD MANGUSADA
}

\author{
I Made Dwie Pradnya Susilal, Ni Made Risna Sumawati ${ }^{2}$ \\ STIKES Bina Usada Bali ${ }^{12}$ \\ e-mail: ${ }^{1}$ dwiepradnya@gmail.com
}

\begin{abstract}
Infections that occur in hospitals called Healthcare Associated Infections (HAIs) are a serious problem for public health. HAIs are infections that patients get during undergoing treatment procedures and medical procedures in health services after jam 48 hours and after $\leq 30$ days after leaving the health facility. One way to reduce nosocomial infections is by washing hands. The purpose of this study was to determine the relationship between the level of knowledge of health workers about the spread of infection with five moment compliance. The design of this research is descriptive correlational research with the approach used is cross sectional approach. Determination of the sample in this study was chosen by the total sampling technique which amounted to 40 people. The data collection of knowledge about the spread of disease using questionnaires and hand washing data five moments using the observation sheet. The statistical test used in this study was Rank Spearman. The results of this study are p value $0.104<0.05$ so that the hypothesis is rejected ie there is no relationship knowledge knowledge of infection spread with the compliance of health workers in hand washing (five moments). Based on the results of this study, it is recommended that the Badung Mangunsada General Hospital be used as a reference in compliance with five moments hand washing by health workers so as to prevent the spread of infection.
\end{abstract}

Keywords: knowledge, hand washing, compliance

\begin{abstract}
ABSTRAK
Infeksi yang terjadi di rumah sakit disebut Healthcare Associated Infections (HAIs) merupakan masalah serius bagi kesehatan masyarakat. HAIs merupakan infeksi yang didapat pasien selama menjalani prosedur perawatan dan tindakan medis di pelayanan kesehatan setelah $\geq 48$ jam dan $\leq 30$ hari setelah keluar dari fasilitas kesehatan. Salah satu cara untuk mengurangi infeksi nosokomial yaitu dengan cuci tangan. Tujuan dari penelitian ini adalah untuk mengetahui hubungan antara tingkat pengetahuan tenaga kesehatan tentang penyebaran infeksi dengan kepatuhan mencuci tangan (five moment). Desain pada penelitian ini adalah penelitian deskriptif korelasional dengan pendekatan yang digunakan adalah pendekatan cross sectional. Penentuan sampel dalam penelitian ini dipilih dengan teknik total sampling yang berjumlah 40 orang. Pengumpulan data pengetahuan tentang penyebaran penyakit menggunakan kuesioner dan data mencuci tangan five moments menggunakan lembar observasi. Uji statistik yang digunakan dalam penelitian ini adalah Rank Spearman. Hasil dari penelitian ini adalah nilai $p$ value $0,104>0,05$ sehingga hipotesis ditolak yaitu tidak ada hubungan pengetahuan penyebaran infeksi dengan kepatuhan tenaga kesehatan dalam mencuci tangan (five moment) Berdasarkan hasil penelitian ini disarankan kepada RSUD Badung Mangunsada agar dapat dijadikan acuan dalam kepatuhan mencuci tangan five momentsoleh petugas kesehatan sehingga dapat mencegah terjadinya penyebaran infeksi.
\end{abstract}

Kata kunci: pengetahuan, cuci tangan, kepatuhan

\section{PENDAHULUAN}

Penyakit infeksi yang didapat di rumah sakit beberapa waktu yang lalu disebut sebagai infeksi nosokomial. Saat ini penyebutannya berubah menjadi infeksi terkait layanan kesehatan atau "HAIs" (Healthcare-Associated Infections). HAIs merupakan infeksi yang didapat pasien selama menjalani prosedur perawatan dan tindakan medis di pelayanan kesehatan setelah $\geq 48$ jam dan $\leq 30$ hari setelah keluar dari fasilitas kesehatan (WHO, 2011). Pasien yang membutuhkan perawatan intensif di Rumah Sakit lebih berisiko terinfeksi HAIs. HAIs dapat memperpanjang hari rawat inap pasien selama 4-5 hari dan bisa menjadi penyebab kematian pasien (IFIC, 2011).

Rumah Sakit merupakan institusi pelayanan masyarakat yang bergerak di bidang pelayanan jasa kesehatan. Oleh karena itu rumah sakit dituntut untuk 
memberikan pelayanan yang bermutu, efektif dan efisien untuk menjamin keselamatan pasien sesuai standar. Sebagai salah satu indikator keselamatan pasien adalah pengurangan risiko infeksi (WHO, 2012). Salah satu cara untuk mengurangi HAIs yaitu dengan cuci tangan (Perry \& Potter, 2010), karena infeksi dapat menular dari pasien ke petugas kesehatan, dari pasien ke pengunjung ataupun dari petugas ke pasien. Maka dari itu sangat penting pengetahuan petugas kesehatan tentang mencuci tangan untuk menerapkan perilaku Five moment for Hand Hygiene sebagai salah satu metode Patient Safety untuk mengurangi angka kejadian HAIs. Pada tahun 2009, WHO mencetuskan Global Patient Safety Challenge dengan Clean Care is Safe Care, merumuskan inovasi strategi penerapan hand hygiene untuk petugas kesehatan dengan My Five Moment For Hand Hygiene yaitu melakukan cuci tangan sebelum bersentuhan dengan pasien, sebelum melakukan prosedur bersih dan steril, setelah bersentuhan dengan pasien, setelah bersentuhan dengan cairan tubuh pasien, setelah bersentuhan dengan lingkungan sekitar pasien. Tetapi hal ini tidak jarang dianggap sepele, walau seluruh petugas telah mendapatkan pelatihan yang baik dan ilmu terbaru terkait masalah cuci tangan tetapi kadang masih ada beberapa oknum yang kurang disiplin untuk menerapkan cuci tangan sesuai prosedur yang telah ada (Sahai, 2016).

Menurut survei WHO, angka kejadian infeksi daerah operasi di dunia berkisarantara 5sampai $34 \%$, di rumah sakit di negara-negara Asia sekitar 3-21\% dengan rata-rata $9 \%$ sedangkan di Indonesia rata-rata prevalensi infeksi sekitar $9,1 \%$ dengan variasi kejadian infeksi sebesar 6,1 - 16 \% (Purwantiningsih, 2015). Berdasarkan data rekammedik RSD Mangusadatahun 2017 angka kejadian HAIs sebanyak 0,7 \%. Sedangkan menurut hasil survey tim Pengendalian dan Pencegahan Infeksi Rumah Sakit Universitas Udayana menyatakan belum adanya data kejadian HAIs.

\section{METODE}

Penelitian ini merupakan penelitian deskriptif korelasional yang bertujuan untuk menguji hipotesis tentang hubungan antara pengetahuan tenaga kesehatan tentang penyebaran infeksi dengan kepatuhan mencuci tangan (five moment) dengan pendekatan cross sectional. Populasi dalam penelitian ini berjumlah 40 orang. Pengambilan sampel pada penelitian ini menggunakan menggunakan tekniktotal sampling. Pengumpulan data menggunakan kuesioner pengetahuan dan lembar observasi. Setelah data semua terkumpul maka akan dilakukan analisis. Analisis yang digunakan yaitu analisis univariate yang berguna untuk mengetahui karakteristik responden (usia, jenis kelamin, tingkat pendidikan, lama kerja), serta variabel penelitian yaitu tingkat pengetahuan responden tentang penyebaran infeksi responden dan kepatuhan tenaga kesehatan mencuci tangan five momentdan analisis bivariat yaitu spearman rank.

\section{HASIL}

\section{Karakteristik Responden}

a. Jenis Kelamin

Tabel 1

Karakteristik Responden Berdasarkan Jenis Kelamin Di Ruang Instalasi Bedah Sentral (IBS) RSUD Kabupaten Badung Mangusada

\begin{tabular}{lcc}
\hline Jenis Kelamin & Frekuensi & Persentase $(\%)$ \\
\hline Laki-laki & 25 & 62.5 \\
\hline Perempuan & 15 & 37.5 \\
\hline Total & 40 & 100.0 \\
\hline
\end{tabular}

Tabel diatas menunjukkan bahwa sebagian besar responden di Instalasi Bedah Sentral (IBS) RSUD Kabupaten Badung Mangusada adalah laki-laki yaitu sebanyak 25 responden $(62,5 \%)$.

\section{b. Kelompok Umur}

Tabel 2

Karakteristik Responden Berdasarkan Kelompok Umur di Instalasi Bedah Sentral (IBS) RSUD Kabupaten Badung Mangusada.

\begin{tabular}{lcc}
\hline Kelompok Umur & Frekuensi & Persentase (\%) \\
\hline $\begin{array}{l}\text { Remaja akhir (17- } \\
25 \text { th) }\end{array}$ & 4 & 10.0 \\
\hline $\begin{array}{l}\text { Dewasa awal (26- } \\
35 \text { th) }\end{array}$ & 20 & 50.0 \\
\hline $\begin{array}{l}\text { Dewasa Akhir (36- } \\
45)\end{array}$ & 16 & 40.0 \\
\hline Total & 40 & 100.0 \\
\hline
\end{tabular}

Tabel 2 diatas menunjukkan bahwa sebagian besar responden di Instalasi Bedah Sentral (IBS) RSUD Kabupaten Badung Mangusada pada kelompok umur dewasa awal (26 -35 tahun) yaitu sebanyak 20 responden $(50 \%)$.

\section{c. Pendidikan}

\section{Tabel 3}

Karakteristik Responden Berdasarkan Pendidikan di Instalasi Bedah Sentral (IBS) RSUD Kabupaten Badung Mangusada. 


\section{Vol. 16 No.2 Mei - Agustus 2021}

\begin{tabular}{lcc}
\hline Pendidikan & Frekuensi & Persentase $(\%)$ \\
\hline S1 & 10 & 25.0 \\
\hline D3 & 30 & 75.0 \\
\hline Total & 40 & 100.0 \\
\hline
\end{tabular}

Tabel 3 diatas menunjukkan bahwa sebagian besar responden di Instalasi Bedah Sentral (IBS) RSUD Kabupaten Badung Mangusada mempunyai pendidikan terakhir di jenjang diploma tiga yaitu sebesar $75 \%$ (30 responden).

\section{d. Lama Bekerja}

Tabel 4

Karakteristik Responden Berdasarkan Lama Bekerja di Instalasi Bedah Sentral (IBS) RSUD Kabupaten Badung Mangusada.

\begin{tabular}{lcc}
\hline Lama bekerja & Frekuensi & Persentase $(\%)$ \\
\hline Baru $(<6$ th) & 13 & 32.5 \\
\hline Sedang $(6-10$ th $)$ & 15 & 37.5 \\
\hline Lama $(>10$ th $)$ & 12 & 30.0 \\
\hline Total & 40 & 100.0 \\
\hline
\end{tabular}

Tabel 4 di atas menunjukkan bahwa sebagian besar responden di Instalasi Bedah Sentral (IBS) RSUD Kabupaten Badung Mangusada mempunyai masa bekerja pada kategori lama (>10 tahun) yaitu sebesar $37,5 \%$ (15 responden).

\section{Variabel Penelitian}

a. Tingkat Pengtahuan Responden tentang penyebaran infeksi

Tabel 5

Variabel Penelitian Tingkat Pengetahuan Responden Tentang Penyebaran Infeksi di Instalasi Bedah Sentral (IBS) RSUD Kabupaten Badung Mangusada

\begin{tabular}{lcc}
\hline $\begin{array}{l}\text { Tingkat } \\
\text { Pengetahuan }\end{array}$ & Frekuensi & Persentase (\%) \\
\hline Baik & 14 & 35.0 \\
\hline Cukup & 22 & 55.0 \\
\hline Kurang & 4 & 10.0 \\
\hline Total & 40 & 100.0 \\
\hline
\end{tabular}

Tabel 5 diatas menunjukkan bahwa sebagian besar responden di Instalasi Bedah Sentral (IBS) RSUD Kabupaten Badung Mangusada mempunyai tingkat pengetahuan tentang penyebaran infeksi pada kategori cukup yaitu sebesar 55\% (22 responden). b. Kepatuhan Tenaga Kesehatan Mencuci Tangan Five Moment

Tabel 6

Variabel Penelitian Kepatuhan Tenaga Kesehatan Mencucui Tangan Five Momentsdi Instalasi Bedah Sentral (IBS) RSUD Kabupaten Badung Mangusada

\begin{tabular}{lcc}
\hline Kepatuhan & Frekuensi & Persentase $(\%)$ \\
\hline Patuh & 8 & 20.0 \\
\hline Kurang patuh & 13 & 32.5 \\
\hline Tidak patuh & 19 & 47.5 \\
\hline Total & 40 & 100.0 \\
\hline
\end{tabular}

Tabel 6 diatas menunjukkan bahwa sebagian besar responden di Instalasi Bedah Sentral (IBS) RSUD Kabupaten Badung Mangusada mempunyai kepatuhan pada kategori tidak patuh yaitu sebesar $47,5 \%$ (19 responden).

\section{Analisa Bivariat}

Tabel 7

Hasil Analisa Hubungan Pengetahuan Penyebaran Infeksi Dengan Kepatuhan Tenaga Kesehatan Dalam Mencuci Tangan (five moment) di ruang Instalasi Bedah Sentral (IBS) RSD Mangusada

\begin{tabular}{|c|c|c|c|c|c|c|c|c|c|}
\hline \multirow{3}{*}{$\begin{array}{l}\text { Pengeta } \\
\text { huan }\end{array}$} & \multicolumn{6}{|c|}{ Kepatuhan } & \multirow{2}{*}{\multicolumn{2}{|c|}{ Total }} & \\
\hline & \multicolumn{2}{|c|}{ Patuh } & \multicolumn{2}{|c|}{$\begin{array}{c}\text { Kurang } \\
\text { patuh }\end{array}$} & \multicolumn{2}{|c|}{$\begin{array}{l}\text { Tidak } \\
\text { patuh }\end{array}$} & & & \\
\hline & $\mathrm{N}$ & $\%$ & $\mathrm{~N}$ & $\%$ & $\mathrm{~N}$ & $\%$ & $\mathrm{~N}$ & $\%$ & \\
\hline Baik & 3 & 21.4 & 7 & 50 & 4 & 28.6 & 14 & 100 & \\
\hline Cukup & 5 & 22.7 & 5 & 22.7 & 12 & 54.6 & 22 & 100 & .104 \\
\hline Kurang & 0 & 0 & 1 & 25.0 & 3 & 75.0 & 4 & 100 & \\
\hline Total & 8 & 20.0 & 13 & 32.5 & 19 & 47.5 & 40 & 100 & \\
\hline
\end{tabular}

Tabel 7 di atas menunjukkan dari perhitungan spearman rho, didapatkan nilai $\mathrm{p}$ value sebesar 0,104 , sehingga dapat disimpulkan bahwa hipotesis dari penelitian ini ditolak yaitu tidak ada hubungan pengetahuan penyebaran infeksi dengan kepatuhan tenaga kesehatan dalam mencuci tangan (five moment) di ruangInstalasi Bedah Sentral (IBS) RSD Mangusada.

\section{PEMBAHASAN}

Hasil penelitian ini menunjukan bahwa sebagian besar responden dengan jenis kelamin lakilaki yaitu sebanyak 25 responden $(62,5 \%)$, dengan dominan berada pada kelompok umur dewasa awal (26-35 tahun) yaitu sebanyak 20 responden (50\%), dan 
dominan dengan pendidikan diploma III yaitu sebanyak 30 responden $(75 \%)$ dan dominan lama bekerja pada kategori sedang (6-10th) yaitu sebanyak 15 responden. Menurut peneliti, karakteristik responden sangat tergantung dari kondisiresponden di tempat penelitian.

Hasil penelitian ini menunjukkan bahwa sebagian besar responden di Instalasi Bedah Sentral (IBS) RSUD Kabupaten Badung Mangusada mempunyai tingkat pengetahuan tentang penyebaran infeksi pada kategori cukup yaitu sebesar 55\% (22 responden). Hasil penelitian ini didukung oleh pernyataan Notoatmodjo (2012), dimana salah satu faktor yang mempengaruhi pengetahuan seseorang adalah tingkat pendidikan responden. Makin tinggi tingkat pendidikan seseorang makin mudah menerima informasi sehingga makin banyak pula pengetahuan yang dimiliki. Sebaliknya pendidikan yang kurang akan menghambat perkembangan sikap seseorang terhadap nilai-nilai yang baru diperkenalkan. Pernyataan tersebut sesuai dengan hasil penelitian ini yaitu sebagian besar responden dengan pendidikan diploma III yaitu sebanyak 30 responden (75\%). Pendidikan diploma III merupakan pendidikan minimal untuk menjadi seorang perawat untuk menerapkan asuhan keperawatan di rumah sakit.

Selain tingkat pendidikan, pengetahuan juga dipengaruhi oleh pengalaman. Pengalaman ini terlihat dari lamanya sesorang bekerja di bidang yang sama. Hasil penelitian ini menunjukkan bahwa responden sebagian besar lama bekerja pada kategori sedang (610th) yaitu sebanyak 15 responden. Pengalaman belajar dalam bekerja yang berkembang memberikan pengetahuan dan keterampilan profesional serta pengalaman belajar selama bekerja akan dapat mengembangkan kemampuan mengambil keputusan yang merupakan manifestasi dan keterpaduan menular secara ilmiah dan etik yang bertolak dari masalah yang nyata dalam bidang keperawatan.

Hasil penelitian ini juga sesuai dengan hasil penelitian Ningsih (2013) yang menyatakan bahwa tingkat pengetahuan perawat tentang infeksi nosokomial dengan kriteria baik yaitu sejumlah 24 responden (54,5\%). Selain peneitian Ningsih (2013), hasil penelitian ini juga sejalan dengan hasil peneliti Sugeng (2014) yang menyatakan sebagian besar perawat di ruang Rawat Inap RSPAW Salatiga Jawa Tengah termasuk dalam kriteria pengetahuan baik yaitu sebanyak 26 perawat $(54,2 \%)$.

Menurut peneliti, pengetahuan responden tentang penyebaran infeksi pada kategori baik disebabkan karena tingkat pendidikan responden yang cukup baik yaitu minimal diploma III. Selain itu juga sebagian besar responden mempunyai pengalaman kerja yang sedang yaitu 6-10 tahun.

Hasil penelitian ini menunjukkan bahwa sebagian besar responden di Instalasi Bedah Sentral (IBS) RSUD Kabupaten Badung Mangusada mempunyai kepatuhan pada kategori tidak patuh yaitu sebesar 47,5\% (19 responden).
Hasil penelitian ini sangat didukung oleh pernyataan Suryoputri (2011) yang menyatakan bahwa kepatuhan petugas kesehatan dalam mencuci tangan (five moment) dipengaruhi oleh beberapa faktor diantaranya faktor karakteristik petugas dan motivasi. Motivasi adalah rangsangan, dorongan atau pembangkit tenaga yang dimiliki seseorang atau sekelompok masyarakat yang mau berbuat dan bekerja sama secara optimal melaksanakan sesuatu yang telah direncanakan untuk mencapai tujuan yang telah ditetapkan (Suryoputri, 2011). Motivasi seseorang berkaitan dengan kebutuhan meliputi tempat dan suasana lingkungan kerja sehingga perawat yang bekerja mengalami penurunan motivasi yang mengakibatkan hasil kerja yang tidak memuaskan dan mengakibatkan tindakan perawat menurun. Dimana motivasi yang baik maka tindakan praktik cuci tangan juga baik dilakukan dan sebaliknya motivasi kurang, tindakan praktik cuci tangan juga kurang dilakukan.

Penelitian ini juga didukung oleh teori dari Sumariyem (2015) yang menyatakan ada hubungan motivasi dengan kepatuhan perawat dalam praktik cuci tangan di ruang Cendana Irna I RSUP Dr. Sardjito Yogyakarta dengan nilai $\mathrm{p}$ value $=0,000$. Motivasi perawat yang tinggi akan meningkatkan kepatuhan perawat dalam melakukan praktik cuci tanganHasil penelitian ini sesuai dengan hasil penelitian Damanik (2010) yang mentakan bahwa sebagian besar perawat dalam melakukan hand hygiene pada kategori tidak patuh atau sebesar 51,7\% (30 responden). Hasil penelitian ini juga sejalan dengan hasil penelitian Sani (2017) yang menyatakan bahwa bahwa sebagian besar responden memiliki kepatuhan dalam melakukan 6 langkah cuci tangan pada kategori tidak patuh 57,4\% (35 responden).

Menurut peneliti kepatuhan perawat dalam kategori tidak patuh disebabkan oleh motivasi perawat itu sendiri. Meskipun rumah sakit telah membuat kebijakan berupa standar prosedur operasional (SPO) kenyataannya masih ada beberapa petugas kesehatan yang tidak melaksanakan kepatuhan sesuai dengan SPO. Jika prosedur tersebut tidak dilakukan tentunya dapat berisiko perpindahan dan penyebaran mikroorganisme dengan sangat mudah melalui tangan perawat ke pasien atau sebaliknya, sehingga akan menambah lamanya waktu dan biaya perawatan. Berdasarkan hasil observasi diketahui bahwa belum ada sanksi yang serius untuk petugas kesehatan yang tidak melakukan hand hygiene sesuai dengan SPO, perawat hanya ditegur dan disuruh untuk mengulangi prosedur yang tidak dilakukan. Belum adanya sanksi yang serius ini dapat membuat perawat untuk melanggar SPO yang telah ditetapkan.

Hasil penelitin ini menunjukkan nilai $\mathrm{p}$ value sebesar 0,104, sehingga dapat disimpulkan bahwa hipotesis dari penelitian ini ditolak yaitu tidak ada hubungan pengetahuan penyebaran infeksi dengan kepatuhan tenaga kesehatan dalam mencuci tangan (five moment) di ruang Instalasi Bedah Sentral (IBS) RSD Mangusada. Hasil penelitian ini didukung oleh 


\section{Vol. 16 No.2 Mei - Agustus 2021}

teori The Health Belief Model oleh Rosenstock dalam Meisa (2012) mengatakan seseorang berperilaku belum tentu didasarkan pada pengetahuan, seperti melakukan pencegahan penyakit tertentu mungkin dikarenakan seseorang tersebut merasa terancam akan terkena penyakit tersebut dan bukan karena pengetahuannya tentang penyakit.

Pengetahuan diperlukan sebagai dorongan psikis dalam menumbuhkan kepercayaan maupun dorongan sikap dan perilaku setiap hari, sehingga dapat diketahui bahwa pengetahuan merupakan stimulus terhadap tindakan seseorang, maka semakin tinggi tingkat pengetahuan seharusnya semakin tinggi pula kepatuhannya (Notoatmodjo, 2010; Susila, 2016). Namun demikian, hal tersebut tidak selalu terjadi, dikarenakan situasi kerja dan lingkungan kerja, selain itu dapat disebabkan kurangnya motivasi responden terhadap kepatuhan mencuci tangan (five moment) dan kurangnya pengetahuan mengenai gejala atau tanda dan dampak yang dapat ditimbulkan. Hal ini sesuai dengan teori yang diungkapkan oleh Smet, B (1994) dalam Suryoputri (2011) yaitu salah satu faktor yang menyebabkan rendahnya kepatuhan seseorang yaitu karena kelalaian seseorang atau rendahnya motivasi serta ketidaktahuan akan tanda-tanda dan gejala yang dapat ditimbulkan.

Hasil penelitian ini sesuai dengan hasil penelitian Komala Dewi (2017) yang menyatakan bahwa tidak ada hubungan yang bermakna yang antara faktor pengetahuan dengan kepatuhan cuci tangan dengan nilai $\mathrm{p}$ value $=0,237$. Hasil penelitian ini juga sejalan dengan hasil penelitian Efendi (2014) yang menyatakan bahwa tidak ada hubungan yang bermakna yang antara pengetahuan dengan kepatuhan cuci tangan dengan nilai $\mathrm{p}$ value $=0,890$. Hasil penelitian ini juga hampir sejalan dengan penelitian yang dilakukan oleh Anggraini (2009) dimana hasilnya adalah tidak ada hubungan yang signifikan tingkat pengetahuan perawat dengan kepatuhan dalam melaksanakan instruksi kerja pemasangan infus dengan nilai p-value 0,798. Penelitian yang dilakukan oleh Rabbani (2010) juga mendapatkan hasil yang serupa dengan hasil penelitian ini yaitu tidak ada hubungan yang bermakna antara pengetahuan dengan perilaku mencuci tangan petugas kesehatan di bagian Ilmu Kesehatan Anak BLU Prof. Dr. RD Kandou Manado dengan nilai p-value 0,160 .

Menurut peneliti pengetahuan tidak berpangaruh terhadap kepatuhan disebebkan karena keenganan, kebiasaan yang telah menahun dan tidak adanya motivasi dalam diri petugas kesehatan. Walaupun sudah diberikan pengetahuan oleh komite PPI (pencegahan dan Pengendalian Infeksi) namun perilaku cuci tangan five moments tidak mengalami perubahan. Kebiasaan yang sudah terbentuk selama bertahun-tahun tidak bisa mengubah secara seketika perilaku yang sudah terbentuk.

\section{KESIMPULAN}

Penelitian ini menunjukkan tidak ada hubungan pengetahuan penyebaran infeksi dengan kepatuhan tenaga kesehatan dalam mencuci tangan (five moment) di ruang Instalasi Bedah Sentral (IBS) RSD Mangusada. Hasil penelitian diharapkan dapat dijadikan acuan atau landasan di dalam kepatuhan mencuci tangan (five moment) sehingga dapat mencegah terjadinya penyebaran infeksi serta dapat dijadikan tambahan informasi aktual sehingga lebih mengenal tentang pentingnya petugas kesehatan mencuci tangan (five moment) sehingga membantu mempercepat proses penyembuhan setelah operasi

\section{DAFTAR PUSTAKA}

1. Della Rindayantika Sari dan Fitrianingsih Endang Cahyawati. 2017. Hubungan Pengetahuan Petugas Kesehatan Dengan Perilaku Five Moment For Hand Hygiene Di RS PKU Muhammadiyah Gamping. Available (online) : http://digilib.unisayogya.ac.id/2385/1/NASKAH\% 20 PUBLI KASI.pdf

2. Damanik. 2010. Kepatuhan Hand Hygiene Di Rumah Sakit Immanuel Bandung. (tesis). Universitas Padjajaran, Bandung.

3. Dwi Sulistyowati. 2016. Hubungan Tingkat Pengetahuan Dan Sikap Perawat Tentang Infekasi Nosokomial Dengan Perilaku Pencegahan Infeksi Nosokomial Di RSUD Dr. Moewardi Surakarta. Available (online) : jurnal.poltekkessolo.ac.id/index.php/JKG/article/download/.../185

4. IFIC. 2011. Basic Concept of Infection Control. Second edition ed. S.L: S.N

5. Inayatur Rabbani. 2010. Hubungan Pengetahuan Terhadap Perilaku uci Tangan Petugas Kesehatan Di Bagian Ilmu Kesehatan Anak BLU RS Prof. Dr. RD Kandou Manado.Available (online): download.portalgaruda.org/ article.php? article $=146268 \&$ val.

6. Ningsih. 2013. Hubungan Antara Tingkat Pengetahuan Dan Motivasi Perawat Dengan Perilaku Pencegahan Infeksi Nosokomial di Rumah Sakit Umum Daerah Sukoharjo. Availble (online): http://eprints.ums.ac.id /27524/23 /NASKAH_PUBLIKASI.pdf

7. Notoatmodjo. 2012. Metodologi Penelitian Kesehatan Jakarta: Rineka Cipta.

8. Susila, I. M. D. P. 2016. Hubungan Tingkat Pengetahuan Dbd Dengan Kejadian DBD Di Banjar Pegok, Desa Sesetan, Kecamatan Denpasar 
Selatan. Jurnal Dunia Kesehatan. Vol. 5. No. 1. 2933.

9. Potter \& Perry. 2010. Fundamental Of Nursing: Consep, Proses and Practice. Edisi 7. Vol. 3. Jakarta : EGC

10. Purwatiningsih. 2015. Pengaruh Penggunaan Hand Sanitizer Terhadap Kepatuhan Cuci Tangan Perawat Pelaksana di Ruang Rawat Inap RSU Assalam Gemolong. Stikes Kusuma Husada. Surakarta

11. Rikayanti. 2013. Hubungan Tingkat Pengetahuan Dengan Perilaku Mencuci Tangan Petugas Kesehatan Di Rumah Sakit Umum Daerah Badung. Available (online) :https://ojs.unud.ac.id/index.php /jch/ article/view/ 7693

12. Saragih, dkk. 2010. Hubungan Karakteristik Perawat dengan Tingkat kepatuhan perawat melakukan cuci tangan di Rumah Sakit Columbia Asia Medan. Available (online) :https://www.academia.edu/6607236/Hubungan_K arakteristik_Perawat_Dengan_Tingkat_kepatuhan Perawat?auto

13. Sugeng. 2014. Hubungan Pengetahuan Dan Sikap Perwat Dengan Pencegahan Infeksi Nosokomial di
Ruang Rawat Inap Rumah Sakit Paru dr. Ario Wirawan Salatiga Jawa Tengah.Available (online): http://eprints.poltek kesjogja .ac.id/187/1/Sugengjurkep.pdf

14. Sumariyem, Q. 2015. Hubungan Motivasi Dengan Kepatuhan Perawat dalam Praktik Hand Hygiene di Ruang Cendana Irna I RSUP Dr. Sardjito Yogyakarta. Available (online) :http://digilib.unisayogya.ac.id/220/1/ naskah\%20pu blikasi.pdf

15. Suryoputri. 2011. Perbedaan Angka Kepatuhan Cuci Tangan Petugas Kesehatan Di RSUP Dr.Kariadi.Studi Di Bangsal Bedah, Anak, Interna, dan ICU. Artikel karya tulis ilmiah. Semarang

16. WHO. 2009. WHO Guidelines on Hand Hygiene in Health Care: A Summary. Geneva.: WHO.

17. WHO. 2011. HAIs Surveilance..available (online) : www.who.int/ bulletin/ volumes/ 89/10/11 -088179 /en

18. Wulandari. 2017. Pengetahuan Dan Penerapan Five Moments Cuci Tangan Perawat di RSUD Sukoharjo. GASTER Vol. XV No. 1 Februari 2017. avalilable (online) : https://www.jurnal.stikesaisyiyah .ac.id/index.php /gaster/.../12 